\title{
Local adaptation at a small geographic scale observed in Juniperus excelsa populations in southern Turkey
}

\author{
Cengiz Yücedă ${ }^{(1)}$, \\ Nuray Çiçek ${ }^{(2)}$, \\ Oliver Gailing ${ }^{(3-4)}$
}

\begin{abstract}
Juniperus excelsa is one of the most common tree species and has a wide geographical and altitudinal distribution in Turkey. It is also resistant to drought and frost damages and can cope with poor soils. In this study, we explore whether there are any differences among eight J. excelsa populations from a narrow geographic region grown in a common garden test site in terms of growth and contents of photosynthetic pigments, proline and nutrients of their 10-year-old saplings. Phenotypic trait differentiation $\left(Q_{S T}\right)$ at all traits, $F_{\mathrm{ST}}$ at neutral SSRs among six of the populations and associations of traits with environmental conditions at provenance regions were also analysed to test for patterns of local adaptation. Sapling traits of eight J. excelsa populations of from Lakes District in Turkey at the test site showed that populations significantly differed for growth, photosynthetic pigments, proline and nutrient contents. The mean height and diameter of 10-year-old saplings were found as $94.5 \mathrm{~cm}$ and $41.6 \mathrm{~mm}$, respectively. Eğirdir-Barla and Sütçüler-Tota populations showed the highest performance for the majority of traits at age 10 compared to all other populations. Nutrient contents in leaves were generally in the sufficiency range reported for plant growth. Considering photosynthetic pigments and proline, it could be concluded that the populations were not exposed to severe stress. Among the environmental variables, the best predictors of growth were annual mean minimum temperature and soil texture at the populations' origin, accounting for $49 \%$ of the variation in height and diameter, respectively. Also, higher phenotypic trait differentiation for most traits than genetic differentiation at neutral genetic markers suggests local adaptation at a small geographic scale. The present study revealed adaptive divergence between populations at a small geographic scale. However, environmental similarity between region of origin and test site was not a good indicator of growth-related traits. The results can be used in the early selection of provenances for J. excelsa for plantation establishment.
\end{abstract}

Keywords: Juniperus Excelsa, Chlorophyll, Proline, Phenotypic Trait Differentiation, Local Adaptation

\section{Introduction}

Understanding how tree species and populations will respond to climatic changes is crucial for the sustainability of forest management (Vizcaíno-Palomar et al. 2019). This issue requires understanding the pattern and scale of local adaptation (Manzanedo et al. 2018), because genetic variation among populations of forest trees at traits highly fluctuates depending on the climate and environmental adaptation (Barbati et al. 2018). Common garden experiments are used to study genetic differentiation at phenotypic traits to detect patterns of local adaptation ( Li et al. 2018, Vizcaíno-Palomar et al. 2019).

For example, common garden tests play an important role in investigating adaptive responses to climate variation (SáenzRomero et al. 2019). Common gardens generally involve the cultivation of tree populations from different geographic regions with different environmental conditions in several common garden experiments established in different environments (Brancalion et al. 2015). In each common garden experiment, saplings are planted using a randomized design (e.g., Randomized Complete Block Design) to minimize local environmental differences and separate between genetic and environmental effects on trait expression (Sewenet 2019). Common gardens were set up to identify the best populations for plantation programs under different environmental conditions (Sáenz-Romero et al. 2019).

Growth traits are strongly affected by the interaction between genotype and environmental resources such as water, soil fertility, etc. (Li et al. 2018). Therefore, it is advisable to conduct the measurements of growth traits in combination with the assessment of other traits in order to decrease the risks associated with sapling transfer (Isaac-Renton et al. 2018). Chlorophylls, carotenoids and proline play crucial roles for example in preventing various diseases associated with oxidative stress (Shah et al. 2017) and are good proxies for the general health of forests (Pakharkova et al. 2020). Macro- and trace elements such as sodium, magnesium, aluminium, 
phosphorus, potassium, calcium, iron, copper and zinc are critical components of different biochemical processes in plants. For this reason, concentrations of these elements in leaves should be sustained within a certain range since their deficiency prevents growth and their excess can cause a toxic effect (Shtangeeva et al. 2017).

Junipers are keystone species in ecosystems of arid regions worldwide because they grow in many harsh environments and are often used for ecological restoration across arid and continental regions. In this regard, J. excelsa is one of the most common tree species and has a wide geographical and altitudinal distribution in Turkey (Yücedag \& Gailing 2013a). As it is resistant to drought and frost damages and can cope with poor soils (Yücedag \& Gailing 2013a), it grows at the boundaries of steppe in the interior parts of the mountains (Douaihy et al. 2011, Yücedag \& Gailing 2013a).

Up to now, there are studies conducted on genetic variation within and among populations of $J$. excelsa based on phenotypic traits measured in the nursery (Yücedag \& Gailing 2013b) and natural populations (Douaihy et al. 2012), isozymes (Hojjati et al. 2009), chloroplast DNA (Gulsoy et al. 2012) and nuclear microsatellite markers (Douaihy et al. 2011, Yücedag \& Gailing 2013a). However, there have been no previous studies on local adaptation to different micro-environments at a small geographic in a mountainous region. In the present study, we assessed the variability in growth and contents of photosynthetic pigments, proline and nutrients of neighbouring $\mathrm{J}$. excelsa populations from distinct environments grown at a common garden test site. Specifically it will be tested: (1) whether there are substantial differences in survival rates across eight $J$. excelsa populations at the test site; (2) whether there are significant differences in growth and contents of photosynthetic pigments, proline and nutrient among the eight populations at the test site; (3) whether there are correlations between the pairs of traits and of environmental variables at the regions of populations' origin with both growth and contents of photosynthetic pigments, proline and nutrient at the test site; (4) whether there is a pattern of local adaptation by comparing phenotypic trait differentiation $\left(\mathrm{Q}_{\mathrm{ST}}\right)$ in the current study and $\mathrm{F}_{\mathrm{ST}}$ at neutral SSRs in an earlier study (Yücedag \& Gailing 2013a) among six of the populations at the same test site, as higher phenotypic differentiation than differentiation at neutral genetic markers could indicate divergent selection on the traits.

\section{Materials and methods}

Planting material and experimental site One-year-old containerized saplings of eight Juniperus excelsa populations from the Lakes District of Turkey were planted at a common garden test site in the northwestern part of Davraz Mountain ( $37^{\circ} 46^{\prime}$ $\mathrm{N}, 30^{\circ} 41^{\prime} \mathrm{E} ; 1500 \mathrm{~m}$ a.s.l.) located about 25 km away from Isparta, Turkey, in early March 2009 (Fig. 1, Tab. 1). Parent trees were between 130 and 140 years old based on tree ring countings using a Pressler increment borer.

The test site was established on a northwestern slope. According to the results of the soil analysis conducted in the Soil Science and Ecology Institute, Çankiri Karatekin University, the soil at test site was sandy, stony and shallow, and was composed by low organic matter component, calcareous $(1.8 \%)$, no salt (0.11\%), too much

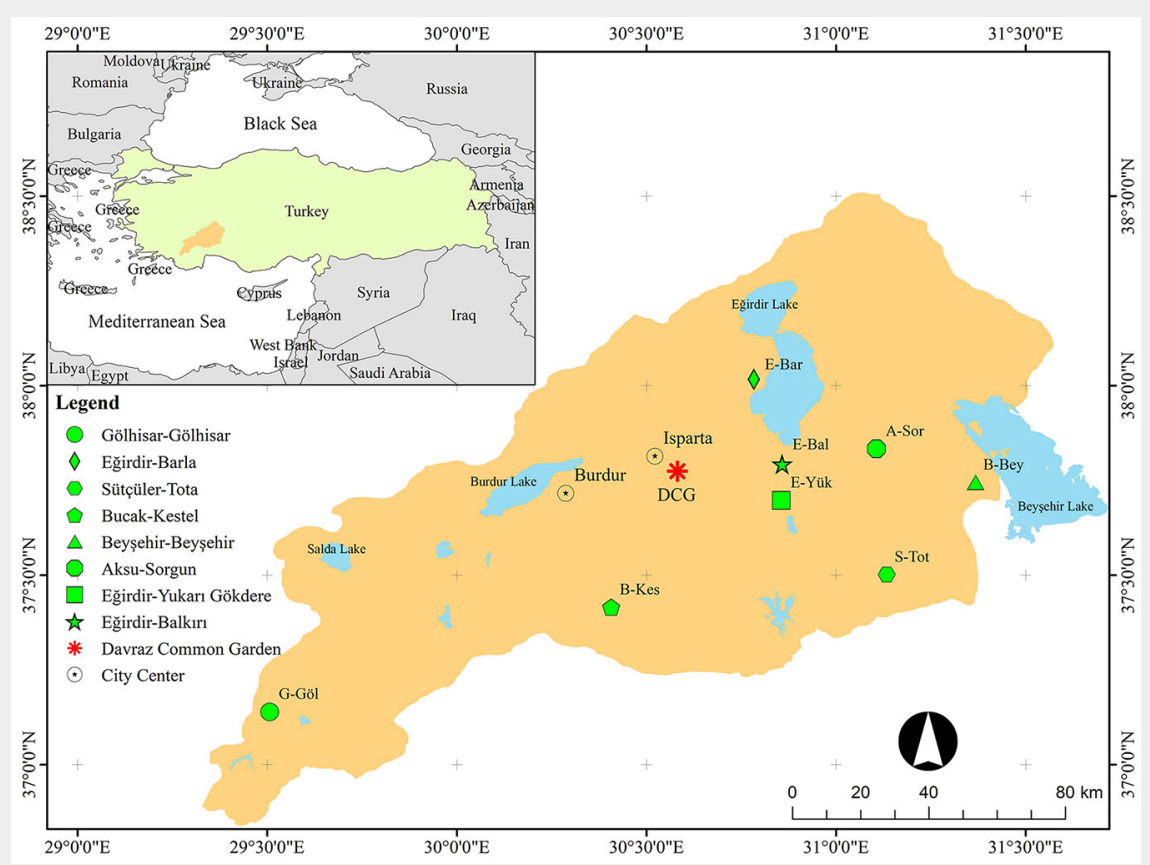

Fig. 1 - Location of populations planted in Davraz Common Garden (DCG) test site. nitrogen ( $0.44 \%)$, much potassium $(411 \mathrm{mg}$ $\mathrm{kg}^{-1}$ ), much iron (18 $\mathrm{mg} \mathrm{kg}^{-1}$ ), adequate phosphorus (9 $\mathrm{mg} \mathrm{kg}^{-1}$ ), adequate magnesium $(0.02 \%)$, adequate manganese (22.7 $\mathrm{mg} \mathrm{kg}-1)$, adequate zinc ( $0.8 \mathrm{mg} \mathrm{kg}^{-1}$ ), adequate copper $\left(1.6 \mathrm{mg} \mathrm{kg}^{-1}\right)$ contents, and with slightly alkaline $\mathrm{pH}$ (7.5). The identification of adequacy in soil properties was made based on Sillanpaeae (1991). A soil cultivation with ripper was done at the test site. The annual average precipitation was $581 \mathrm{~mm}$ and the annual average temperature was $12^{\circ} \mathrm{C}$ (Anonymous 2013).

\section{Experimental design}

The layout of the experiment was a randomized complete block design with three replications. Sufficient homogeneity was achieved within the blocks extending from uphill to downhill, and environmental differences among populations were minimized. Spacing between saplings was $2 \times 3$ $\mathrm{m}$. Each population was represented by 30 saplings (10 saplings per block) grown from seeds in Egirdir Forest Nursery (Yücedag \& Gailing 2013b). The total number of seedlings planted was 240 .

\section{Sampling strategy}

Height, diameter and volume were determined for all the $30 \times 8$ saplings. For the plant nutrient, photosynthetic pigment and proline analyses, five saplings from each of the eight populations (at least one sapling from each block) were randomly sampled (a subset of $5 \times 8$ saplings). About 2 $\mathrm{g}$ leaf samples from each of the saplings were collected in August of 2018 to use as fresh material. They were immediately wrapped in aluminium foil and put on dry ice at the test site. Then, these samples were taken to the Department of Landscape Architecture, Çankiri Karatekin University without breaking the cold chain. Fresh leaf samples were kept at $-20^{\circ} \mathrm{C}$ until the day of analysis. Also, about $100 \mathrm{~g}$ leaf samples from each of the saplings were collected in late September of 2018 to use as dry material. After collecting, these samples were immediately dried at $70{ }^{\circ} \mathrm{C}$ in an oven for five days in the laboratory of Burdur Mehmet Akif Ersoy University and then dried samples were taken to the Department of Landscape Architecture, Çankiri Karatekin University.

\section{Plant analyses}

The dried leaf samples were digested using the dry-ashing method in a muffle furnace at $500{ }^{\circ} \mathrm{C}$ for 6 hours, later dissolved in $10 \mathrm{~N}$ nitric acid $\left(\mathrm{HNO}_{3}\right)$, and finally extracts were filtered and stored in plastic sample jars until the day of analysis of mineral nutrients (Miller 2004). The concentrations of $\mathrm{P}, \mathrm{K}, \mathrm{Ca}, \mathrm{Mg}, \mathrm{Na}, \mathrm{Cu}, \mathrm{Mn}$, Fe and $\mathrm{Zn}$ were determined by ICP-OES (Optima ${ }^{\circledR}$ 2100 DV, Perkin-Elmer ,Waltham, MA, USA). Nitrogen concentration was determined through the method developed by Kjeldahl (1883). 


\section{Photosynthetic pigment analysis}

The fresh leaf samples ( $250 \mathrm{mg}$ ) were cut into small pieces and homogenized in 10 $\mathrm{mL}$ of acetone $(90 \%, \mathrm{v} / \mathrm{v})$. The extract was then filtered and the absorbance of the extract was measured at 645, 652, 663 and $470 \mathrm{~nm}$ using a spectrophotometer (UV/ VIS-1201, Shimadzu Corp., Kyoto, Japan). The concentrations of chlorophylls (chl) and carotenoid (car) were calculated based on Lichtenthaler (1987).

\section{Proline analysis}

Free proline was extracted with $3 \%$ sulphosalicylic acid from fresh leaves ( $0.5 \mathrm{~g}$ ) and determined according to the method of Bates et al. (1973). Extracts $(2 \mathrm{~mL})$ were maintained for $1 \mathrm{~h}$ in boiling water with the addition of $2 \mathrm{~mL}$ ninhydrin and $2 \mathrm{~mL}$ glacial acetic acid. Cold toluene $(4 \mathrm{~mL})$ was added afterwards and shaken with a vortex. Finally, absorbance was read at $520 \mathrm{~nm}$. The proline concentration was determined from a standard curve using L-Proline and expressed in $\mathrm{mmol} \mathrm{kg}^{-1} \mathrm{FW}$.

\section{Growth analysis}

For the growth analysis, height $(\mathrm{cm})$ and diameter $(\mathrm{mm})$ of 30 saplings from each of the populations were measured in late September of 2018 using a tape measurer and a digital calliper, respectively. Furthermore, volumes of saplings were calculated using the equation developed for J. excelsa by Eler (1988) as follows (eqn. 1):

$$
V=0.035623846 \cdot d^{2.27029466} \cdot h^{0.595058217}
$$

where $V$ is the volume $\left(\mathrm{cm}^{3}\right), d$ is the diameter and $h$ the height of saplings.
Environmental variables

Soil texture for the region of origin of each of the eight populations was determined by using the feel method (FAO 2020). Accordingly, sandy, sandy loam and sand clay contained $<10 \%(=1), 10-30 \%(=2)$ and $35-55 \%$ clay $(=3)$, respectively.

Data of total annual precipitation ( $\mathrm{mm}$ ), annual mean temperature $\left({ }^{\circ} \mathrm{C}\right)$, annual mean maximum and minimum temperatures $\left({ }^{\circ} \mathrm{C}\right)$ in the eight meteorological stations (ms), that were the closest to the studied populations and common garden test site, were provided from Turkish State Meteorological Service. Then, total annual precipitation of populations $(p)$ were interpolated using the formula of Schreiber (1904) as follows (eqn. 2):

$$
P_{p}=P_{m s}+\left(h_{p}-h_{m s}\right) \cdot \frac{54}{100}
$$

where $P_{\mathrm{p}}$ and $P_{\mathrm{ms}}$ are the total annual precipitations of populations and meteorological stations $(\mathrm{mm}), h_{\mathrm{p}}$ and $h_{\mathrm{ms}}$ are altitudes of populations and meteorological stations (m), 54/100 is a constant showing $54 \mathrm{~mm}$ of precipitation increases at every 100 meters. Annual mean temperature, annual mean maximum and minimum temperatures of populations were interpreted using the lapse rate formula as follows (eqn. 3 ):

$$
T_{p}=T_{m s} \pm\left(h_{p}-h_{m s}\right) \cdot 0.005
$$

where $T_{\mathrm{p}}$ and $T_{\mathrm{ms}}$ are the temperatures of populations and meteorological stations $\left({ }^{\circ} \mathrm{C}\right), 0.005$ is a constant (Kilinç et al. 2006). Precipitation effectiveness index was calculated by taking the ratio of total annual precipitation to the annual mean maximum temperature, and then this index was used to determine the climate type for each population (Erinç 1965).

Topographic wetness index was calculated as follows (eqn. 4):

$$
T W I=\ln \left(\frac{\alpha_{s}}{\tan \beta}\right)
$$

where $\alpha_{s}$ is the specific catchment area $\left(\mathrm{m}^{2}\right), \tan \beta$ is the local slope (Qin et al. 2011). Calculations were made using ArcMap $^{\circledast}$ v. 10.4.1 (ESRI, Redlands, CA, USA). Artificial digital elevation models with a series of resolutions finer than $25 \mathrm{~m}$ were used to evaluate TWI quantitatively.

\section{Statistical analysis}

Normal distribution of the data in height, diameter and volume was tested through a Kolmogorov-Smirnov test. Parametric tests were performed as residuals of the model were homoscedastic. Mean, standard deviation, $\mathrm{F}$ ratio and probability ( $\mathrm{P}$-value) of all the traits were calculated and compared among populations through analysis of variance (ANOVA) and adjusted Duncan's multiple range tests $(p<0.05)$. The means of height and diameter were compared between soil textures using a t-test. Quantitative trait differentiation (Spitze 1993) among populations was estimated for all traits as follows (eqn. 5):

$$
Q_{s t}=\frac{\sigma_{G(\text { among })}^{2}}{\sigma_{G(\text { among })}^{2}+2 \sigma_{G(\text { within })}^{2}}
$$

where $\sigma^{2} G$ (among) is the variance among populations and $\sigma^{2} c$ (within) the variance within populations. Q Q for the six populations for which $F_{S T}$ values were available, but also for all eight populations. $Q_{S T}$ describes the genetic differentiation at traits among provenances in the

\begin{tabular}{|c|c|c|c|c|c|c|c|c|c|c|c|}
\hline Population (test site) & $\begin{array}{l}\text { Altitude } \\
\text { (m a.s.l.) }\end{array}$ & Aspect & Coords & $\begin{array}{l}\text { Soil } \\
\text { Texture }\end{array}$ & $\begin{array}{l}\text { TAP } \\
(\mathrm{mm})\end{array}$ & $\begin{array}{l}\text { MAT } \\
\left({ }^{\circ} \mathrm{C}\right)\end{array}$ & $\begin{array}{c}\text { MAT }_{\max } \\
\left({ }^{\circ} \mathrm{C}\right)\end{array}$ & $\begin{array}{c}\mathrm{MAT}_{\text {min }} \\
\left({ }^{\circ} \mathrm{C}\right)\end{array}$ & PEI & Climate & TWI \\
\hline Gölhisar-Gölhisar (G-Göl) & 1413 & SE & $\begin{array}{l}36^{\circ} 57.115^{\prime} \mathrm{N} \\
29^{\circ} 27.236^{\prime} \mathrm{E}\end{array}$ & Sandy loam & 510.7 & 11.2 & 24.2 & -0.1 & 21.1 & Semi-arid & 6.6 \\
\hline Egirdir-Barla (E-Bar) & 1027 & SE & $\begin{array}{l}37^{\circ} 58.162^{\prime} \mathrm{N} \\
30^{\circ} 46.289^{\prime} \mathrm{E}\end{array}$ & Sandy clay & 542.2 & 13.8 & 23.8 & 4.5 & 22.8 & Semi-arid & 5.7 \\
\hline Sütçüler-Tota (S-Tot) & 1546 & NE & $\begin{array}{l}37^{\circ} 34.678^{\prime} \mathrm{N} \\
31^{\circ} 04.306^{\prime} \mathrm{E}\end{array}$ & Sandy clay & 1407.2 & 11.2 & 23.3 & 1.2 & 60.4 & Much humid & 7.7 \\
\hline Bucak-Kestel (B-Kes) & 1197 & SE & $\begin{array}{l}37^{\circ} 24.863^{\prime} \mathrm{N} \\
30^{\circ} 21.036^{\prime} \mathrm{E}\end{array}$ & Sandy loam & 745.8 & 13.2 & 25.7 & 1.9 & 29.0 & Semi-humid & 13.4 \\
\hline Beysehir-Beysehir (B-Bey) & 1151 & NE & $\begin{array}{l}37^{\circ} 39.043^{\prime} \mathrm{N} \\
31^{\circ} 42.058^{\prime} \mathrm{E}\end{array}$ & Sandy clay & 483.4 & 11.1 & 23.3 & -1.3 & 20.8 & Semi-arid & 7.1 \\
\hline Aksu-Sorgun (A-Sor) & 1416 & NE & $\begin{array}{l}37^{\circ} 50.488^{\prime} \mathrm{N} \\
31^{\circ} 05.782^{\prime} \mathrm{E}\end{array}$ & Sandy clay & 964.5 & 11.0 & 23.2 & -2.0 & 41.6 & Humid & 6.4 \\
\hline Egirdir-Yukari Gökdere (E-Yuk) & 1150 & SE & $\begin{array}{l}37^{\circ} 40.558^{\prime} \mathrm{N} \\
30^{\circ} 50.570^{\prime} \mathrm{E}\end{array}$ & Sandy clay & 918.9 & 11.8 & 22.3 & 1.4 & 41.2 & Humid & 8.5 \\
\hline Egirdir-Balkiri (E-Bal) & 1493 & $\mathrm{E}$ & $\begin{array}{l}37^{\circ} 47.101^{\prime} \mathrm{N} \\
30^{\circ} 48.981^{\prime} \mathrm{E}\end{array}$ & Sandy loam & 1104.1 & 10.0 & 20.5 & -0.4 & 53.9 & Humid & 9.8 \\
\hline Davraz Common Garden (DCG) & 1500 & NW & $\begin{array}{l}37^{\circ} 46.103^{\prime} \mathrm{N} \\
30^{\circ} 41.285^{\prime} \mathrm{E}\end{array}$ & Sandy & 843.8 & 9.8 & 20.0 & -0.6 & 42.2 & Humid & 8.6 \\
\hline
\end{tabular}

Tab. 1 - Geographic positions, environmental and climatic features of Davraz common garden and the eight Juniperus excelsa populations used in the present study (modified from Yücedag \& Gailing 2013a). (TAP): total annual precipitation; (MAT): mean annual temperature; $\left(\mathrm{MAT}_{\max }\right)$ : mean annual maximum temperature; $\left(\mathrm{MAT}_{\min }\right)$ : mean annual minimum temperature; (PEI): precipitation effectiveness index; (TWI): topographic wetness index. 

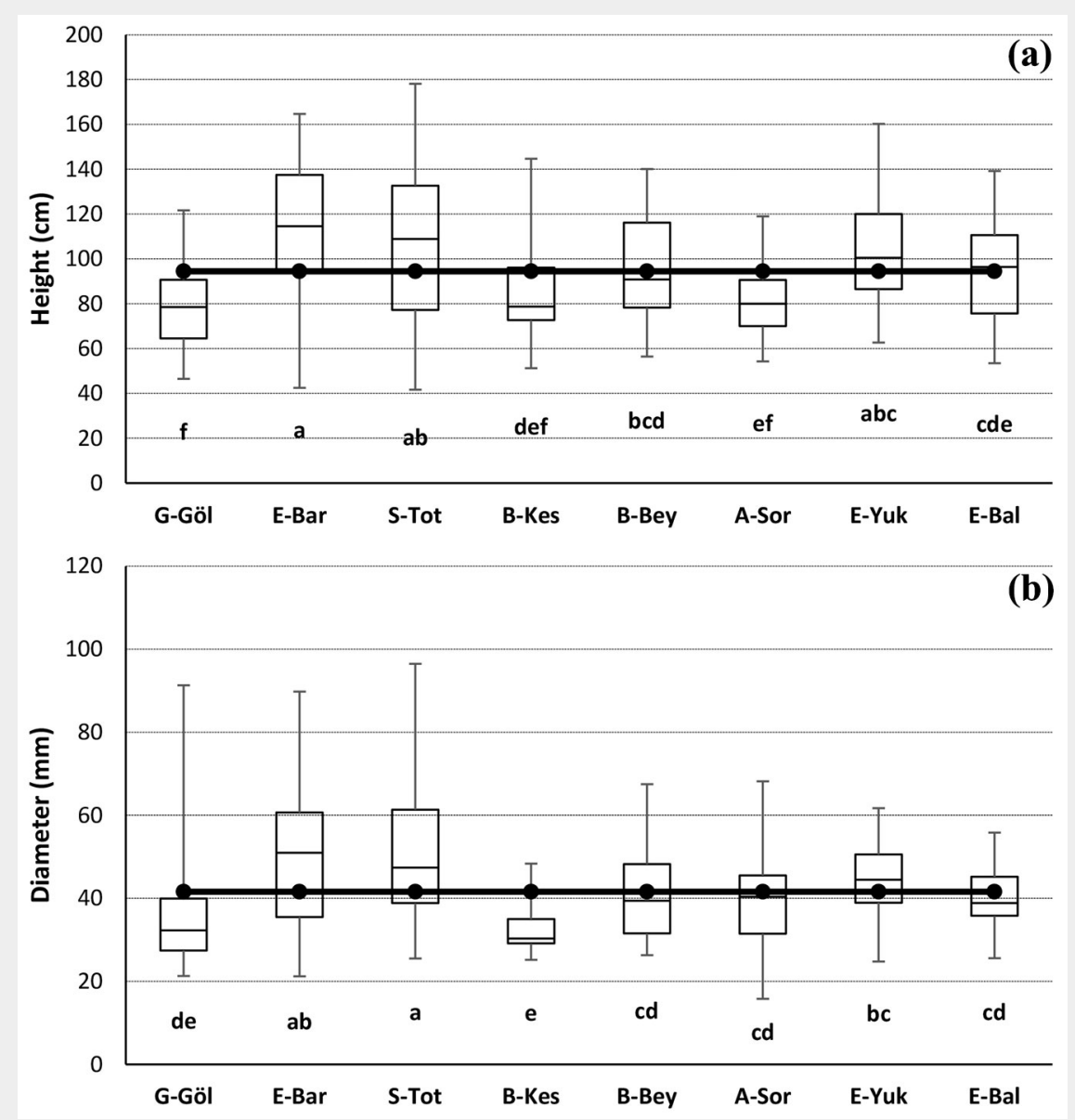

Fig. 2 - Boxplot diagrams of height (a) and diameter (b) of 10-years-old saplings from eight $J$. excelsa populations grown at the common garden test site $\left(F_{\text {height }}=8.429\right.$, $\left.\mathrm{p}<0.001 ; \mathrm{F}_{\text {diamater }}=8.357, \mathrm{p}<0.001\right)$. In both panels, different letters indicate significant differences $(p<0.05)$ between the mean of the populations. Blue lines show the grand means of height $(94.47 \mathrm{~cm})$ and diameter $(41.6 \mathrm{~mm})$.

common garden test in which the environmental variance is minimized. Since we had no pedigree information we estimated broad-sense $Q_{S T}$ which can include components of non-additive genetic components

(dominance, epistasis, maternal effects). However, genetic variance for complex traits has been reported to be additive in most cases (Hill et al. 2008). In addition, the correlations of both nutrient contents

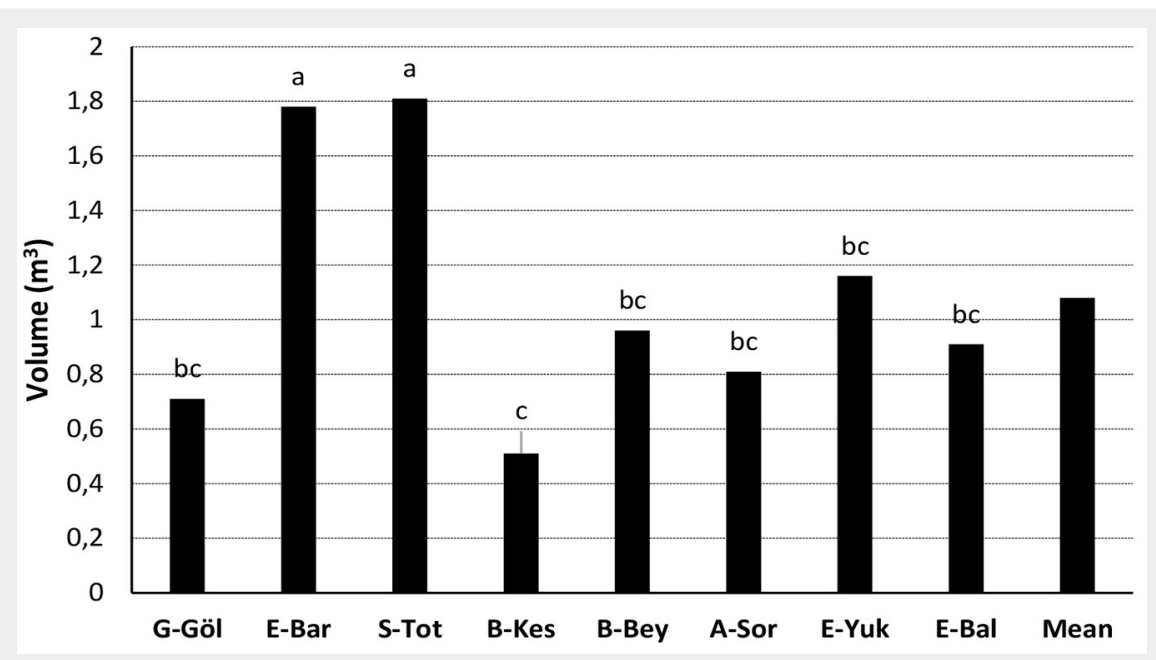

Fig. 3 - Mean volumes of 10-years-old saplings from eight J. excelsa populations grown at the common garden test site $\left(F_{\text {volume }}=8.229, \mathrm{p}<0.001\right)$. Different letters indicate significant differences $(p<0.05)$ between the mean of the populations. and environmental variables (total annual precipitation, annual mean temperature, annual mean maximum and minimum temperatures, precipitation effectiveness index, topographic wetness index and soil texture) at the populations' regions of origin with growth, photosynthetic pigments and proline were performed using Pearson's correlation coefficients. Differences among populations were visualized using a dendrogram from hierarchical cluster analyses based on growth, photosynthetic pigments, proline and nutrient contents. All statistical analyses were conducted using SPSS $^{\circledast}$ v. 25 (IBM, Armonk, NY, USA).

\section{Results}

We found very few saplings with damaged crown, but the survival rate of all populations was $100 \%$.

The distribution of height and diameter for 10-year-old saplings of eight $J$. excelsa populations are presented in Fig. 2. The ANOVA showed significant differences among populations for height and diameter $(\mathrm{p}<0.001)$. E-Bar and G-Göl populations showed the highest $(115.06 \mathrm{~cm})$ and lowest $(78.08 \mathrm{~cm})$ performances in height, while $\mathrm{S}$-Tot and B-Kes populations showed the best $(50.8 \mathrm{~mm})$ and worst $(32.5 \mathrm{~mm})$ performances in diameter. The mean height and diameter were $94.47 \mathrm{~cm}$ and $41.6 \mathrm{~mm}$, respectively (Fig. 2). The differences (\%) of the populations with the highest height and diameter from the grand mean of the populations in the current study were $22 \%$. The differences between the populations with the highest (E-Bar and S-Tot) and lowest (G-Göl and B-Kes) heights and diameters were $47 \%$ and $56 \%$, respectively. The highest mean volumes were $52.07 \mathrm{~cm}^{3}$ and $51.13 \mathrm{~cm}^{3}$ in S-Tot and E-Bar populations, respectively. Besides, B-Kes population had the lowest mean volume $\left(14.82 \mathrm{~cm}^{3}-\right.$ Fig. 3). Overall, sapling materials from E-Bar, STot and E-Yuk were above the general averages of height, diameter and volume compared to the other populations (Fig. 2, Fig. 3). The regions of these populations also had relatively high annual mean minimum temperatures as compared to the other populations, but the same soil texture (Tab. 1).

ANOVA revealed significant differences among populations for all photosynthetic pigments and proline $(p<0.05)$. G-Göl population had the highest total $\mathrm{chl}(0.727 \mathrm{mg}$ $\left.\mathrm{g}^{-1} \mathrm{FW}\right)$, chl $a\left(0.405 \mathrm{mg} \mathrm{g}^{-1} \mathrm{FW}\right)$ and chl $a+b$ (0.567 $\left.\mathrm{mg} \mathrm{g}^{-1} \mathrm{FW}\right)$, while E-Bar population had the highest $\mathrm{chl} b\left(0.167 \mathrm{mg} \mathrm{g}^{-1} \mathrm{FW}\right)$ and car (0.192 $\mathrm{mg} \mathrm{g}^{-1} \mathrm{FW}$ ). S-Tot population had the highest proline concentration $(0.523$ mmol kg-1 FW). The lowest total chl (0.394 $\left.\mathrm{mg} \mathrm{g}^{-1} \mathrm{FW}\right)$, chl $a\left(0.182 \mathrm{mg} \mathrm{g}^{-1} \mathrm{FW}\right)$ and chl $a+b\left(0.318 \mathrm{mg} \mathrm{g}^{-1} \mathrm{FW}\right)$ were found in E-Bal population. The lowest chl $b\left(0.111 \mathrm{mg} \mathrm{g}^{-1}\right.$ $\mathrm{FW}$ ) was determined in E-Yuk population. The lowest car ( $\left.0.117 \mathrm{mg} \mathrm{g}^{-1} \mathrm{FW}\right)$ and proline $\left(0.358 \mathrm{mmol} \mathrm{kg}^{-1} \mathrm{FW}\right)$ were found in $\mathrm{B}$ Kes population. E-Bal population had significantly lower chl $a$ than the other popu- 
Tab. 2 - Mean \pm standard deviation, range, $\mathrm{F}$ ratio and significance $(\mathrm{p})$ for photosynthetic pigments and proline of J. excelsa 10-yearold saplings. (Total chl): total chlorophyll; (chl $a, b$ and $a+b$ ): Chlorophyll $a, b$ and $a+b$; (car): carotenoid. Different letters in the columns indicate significant differences $(p<0.05)$ between population means.

\begin{tabular}{|c|c|c|c|c|c|c|}
\hline Populations (Label) & $\begin{array}{l}\text { Total chl } \\
\left(\mathrm{mg} \mathrm{g}^{-1} \mathrm{FW}\right)\end{array}$ & $\begin{array}{l}\operatorname{chl} a \\
\left(\mathrm{mg} \mathrm{g}^{-1} \mathrm{FW}\right)\end{array}$ & $\begin{array}{l}\operatorname{chl} b \\
\left(\mathrm{mg} \mathrm{g}^{-1} \mathrm{FW}\right)\end{array}$ & $\begin{array}{l}\operatorname{chl} a+b \\
\left(\mathrm{mg} \mathrm{g}^{-1} \mathrm{FW}\right)\end{array}$ & $\begin{array}{l}\mathrm{car} \\
\left(\mathrm{mg} \mathrm{g}^{-1} \mathrm{FW}\right)\end{array}$ & $\begin{array}{l}\text { Proline } \\
\text { (mmol/kg FW) }\end{array}$ \\
\hline Gölhisar-Gölhisar (G-Göl) & $0.727 \pm 0.12^{a}$ & $0.405 \pm 0.03^{a}$ & $0.162 \pm 0.03^{a b}$ & $0.567 \pm 0.05^{a}$ & $0.184 \pm 0.02^{a b}$ & $0.475 \pm 0.04 \mathrm{bc}$ \\
\hline Egirdir-Barla (E-Bar) & $0.657 \pm 0.07^{a b}$ & $0.363 \pm 0.04^{\mathrm{ab}}$ & $0.167 \pm 0.02^{a}$ & $0.529 \pm 0.06^{\mathrm{ab}}$ & $0.192 \pm 0.02^{a}$ & $0.514 \pm 0.03 a b$ \\
\hline Sütçüler-Tota (S-Tot) & $0.610 \pm 0.08 \mathrm{bc}$ & $0.350 \pm 0.04^{b}$ & $0.150 \pm 0.01 \mathrm{abc}$ & $0.500 \pm 0.06^{a b}$ & $0.136 \pm 0.07^{b c}$ & $0.523 \pm 0.01^{a}$ \\
\hline Bucak-Kestel (B-Kes) & $0.568 \pm 0.13^{b c}$ & $0.328 \pm 0.07^{b}$ & $0.134 \pm 0.02^{\mathrm{bcd}}$ & $0.462 \pm 0.10^{b c}$ & $0.117 \pm 0.06^{c}$ & $0.358 \pm 0.01^{d}$ \\
\hline Beysehir-Beysehir (B-Bey) & $0.500 \pm 0.06^{\mathrm{cd}}$ & $0.266 \pm 0.04^{c}$ & $0.130 \pm 0.01 \mathrm{~cd}$ & $0.396 \pm 0.05^{\mathrm{cd}}$ & $0.142 \pm 0.02^{b c}$ & $0.517 \pm 0.03^{a b}$ \\
\hline Aksu-Sorgun (A-Sor) & $0.449 \pm 0.02^{d}$ & $0.243 \pm 0.01^{c}$ & $0.117 \pm 0.01^{d}$ & $0.360 \pm 0.02$ de & $0.140 \pm 0.01^{b c}$ & $0.439 \pm 0.07^{c}$ \\
\hline Egirdir-Yukari Gökdere (E-Yuk) & $0.417 \pm 0.09^{d}$ & $0.239 \pm 0.03^{c}$ & $0.111 \pm 0.01^{d}$ & $0.349 \pm 0.03 \mathrm{de}$ & $0.139 \pm 0.02^{b c}$ & $0.365 \pm 0.01^{d}$ \\
\hline Egirdir-Balkiri (E-Bal) & $0.394 \pm 0.03^{d}$ & $0.182 \pm 0.02^{d}$ & $0.136 \pm 0.04 \mathrm{bcd}$ & $0.318 \pm 0.04^{e}$ & $0.122 \pm 0.02^{c}$ & $0.377 \pm 0.01^{d}$ \\
\hline Mean & $0.540 \pm 0.14$ & $0.297 \pm 0.08$ & $0.138 \pm 0.03$ & $0.435 \pm 0.10$ & $0.147 \pm 0.04$ & $0.446 \pm 0.07$ \\
\hline Range & $0.280-0.860$ & $0.160-0.440$ & $0.090-0.200$ & $0.290-0.630$ & $0.020-0.210$ & $0.340-0.560$ \\
\hline$F$ & 10.883 & 19.277 & 4.375 & 14.295 & 2.820 & 22.010 \\
\hline$p$ & $<0.001$ & $<0.001$ & 0.002 & $<0.001$ & 0.021 & $<0.001$ \\
\hline
\end{tabular}

lations. B-Kes, E-Yuk and E-Bal populations were significantly different from other populations in terms of proline (Tab. 2).

According to the ANOVA, there were significant differences between populations for nutrient contents $(\mathrm{p}<0.05)$. The highest means of $\mathrm{P}(0.26 \%), \mathrm{K}(73 \%), \mathrm{Mg}(20 \%)$, $\mathrm{Cu}\left(9.15 \mathrm{mg} \mathrm{kg}^{-1}\right)$ and $\mathrm{Zn}\left(21.29 \mathrm{mg} \mathrm{kg}^{-1}\right)$ were found in S-Tot population. G-Göl population showed the highest means of $\mathrm{N}$ (1.35\%) and $\mathrm{Ca}(1.62 \%)$. The highest means of $\mathrm{Mn}\left(42.12 \mathrm{mg} \mathrm{kg}^{-1}\right)$ and $\mathrm{Fe}\left(76.75 \mathrm{mg} \mathrm{kg}^{-1}\right)$ were determined in E-Bar and E-Bal populations, respectively. The lowest means of $P$ (0.18\%), K (62\%) and $\left.\mathrm{Zn} \mathrm{(13.46} \mathrm{mg} \mathrm{kg}^{-1}\right)$ were found in G-Göl population. E-Yuk population revealed the lowest means of $\mathrm{N}$ (1.19\%), Mg (0.12\%) and Fe (51.19 $\left.\mathrm{mg} \mathrm{kg}^{-1}\right)$. EBar population had the lowest means of $\mathrm{Ca}$ (1.34\%) and $\mathrm{Cu}(6.14 \%)$. The lowest mean of Mn (28.85 $\left.\mathrm{mg} \mathrm{kg}^{-1}\right)$ was found in B-Kes population. E-Yuk population had significantly lower Mg than the other populations. E-Bar and B-Bey populations had significantly higher and lower $\mathrm{Mn}$ then the other populations (Tab. 3).

Proline $\left(Q_{S T}=0.71\right), \mathrm{chl} b\left(Q_{S T}=0.67\right), \mathrm{chl} a$ $\left(Q_{\mathrm{ST}}=0.60\right)$ and chl $a+b\left(Q_{\mathrm{sT}}=0.57\right)$ had the highest $Q_{\text {st }}$ values among J. excelsa populations, while volume $\left(Q_{S T}=0.05\right)$ and diameter $\left(Q_{S T}=0.17\right)$ had the lowest $Q_{S T}$ values (Fig. 4).

There were positive correlations between height and Zn, and between diameter and $\mathrm{Fe}$. On the other hand, there were positive correlations of $\mathrm{N}$ with both total $\mathrm{chl}$ and chl $b$ and of Mg with total chl, chl $a$ and $b$, car and proline. There was no correlation between phenotypic and photosynthetic traits. While height was strongly correlated with diameter $(R=0.88)$ and volume $(R=$ $0.90)$, diameter had a strong correlation with volume $(R=0.98, p<0.05-T a b . S 1$ in Supplementary material). However, there was no association between growth and distances of populations from the test site.
According to $t$-test results, saplings from populations with sandy clay had higher height and diameter than those from populations with sandy loam ( $t_{\text {height }}=4.549, p<$ $\left.0.001 ; t_{\text {diameter }}=5.453 ; p<0.001\right)$. Annual mean maximum temperature was positively correlated with total chl $(R=0.67)$, chl $a(R=0.74)$ and chl $a+b(R=0.67, \mathrm{p}<$ 0.05 - Fig. S1 in Supplementary material) and annual mean minimum temperature was positively correlated with height $(R=$ $0.70, p<0.05$ - Fig. 5). Finally, topographic wetness index was negatively correlated with $\operatorname{car}(R=-0.73)$ and proline $(R=-0.74-$ Fig. S2). J. excelsa saplings originating from regions with sandy clay and higher annual mean minimum temperature grew faster than those from regions with sandy loam and lower annual mean temperature. Populations with similar environmental conditions (low annual mean minimum temperature and sandy loam) as at the test site showed a comparatively low height and di-

Tab. 3 - Mean \pm standard deviation, range, $F$ ratio and significance $(\mathrm{p})$ for the nutrient contents of J. excelsa 10-year-old saplings. $(\mathrm{N})$ : Nitrogen; (P): Phosphorous; (K): Potassium; (Ca): Calcium; (Mg): Magnesium; (Cu): Copper; (Mn): Manganese; (Fe): Iron; (Zn): Zinc. Different letters in the columns indicate significant differences $(p<0.05)$ between the population means.

\begin{tabular}{|c|c|c|c|c|c|c|c|c|c|}
\hline Pop & $\begin{array}{l}\mathrm{N} \\
(\%)\end{array}$ & $\begin{array}{l}P \\
(\%)\end{array}$ & $\begin{array}{l}K \\
(\%)\end{array}$ & $\begin{array}{l}\mathrm{Ca} \\
(\%)\end{array}$ & $\begin{array}{l}M \\
(\%)\end{array}$ & $\begin{array}{l}\mathrm{Cu} \\
\left(\mathrm{mg} \mathrm{kg}^{-1}\right)\end{array}$ & $\begin{array}{l}\mathrm{Mn} \\
\left(\mathrm{mg} \mathrm{kg}^{-1}\right)\end{array}$ & $\begin{array}{l}\mathrm{Fe} \\
\left(\mathrm{mg} \mathrm{kg}^{-1}\right)\end{array}$ & $\begin{array}{l}\mathrm{Zn} \\
\left(\mathrm{mg} \mathrm{kg}^{-1}\right)\end{array}$ \\
\hline G-Göl & $1.35 \pm 0.14^{a}$ & $0.18 \pm 0.02^{d}$ & $0.62 \pm 0.07^{b}$ & $1.62 \pm 0.14{ }^{\mathrm{ab}}$ & $0.17 \pm 0.01^{c}$ & $6.52 \pm 0.76^{b c}$ & $37.15 \pm 1.68^{b}$ & $54.79 \pm 6.13^{c}$ & $13.46 \pm 0.89^{f}$ \\
\hline E-Bar & $1.33 \pm 0.06^{a}$ & $0.24 \pm 0.01$ & $0.69 \pm 0.03$ & $1.34 \pm 0.09^{c d}$ & $0.18 \pm 0.04 a b c$ & ${ }^{c} 6.14 \pm 0.60^{c}$ & $42.12 \pm 2.92^{a}$ & $58.00 \pm 9.15^{b c}$ & $20.95 \pm 0.60^{a}$ \\
\hline S-Tot & $1.26 \pm 0.05 a b$ & ${ }^{b} 0.26 \pm 0.03^{a}$ & $0.73 \pm 0.04^{a}$ & $1.54 \pm 0.23 \mathrm{abcd}$ & $0.20 \pm 0.03 \mathrm{ab}$ & $9.15 \pm 1.22^{a}$ & $32.80 \pm 3.89$ & $72.28 \pm 10.92^{a}$ & $21.29 \pm 1.28^{a}$ \\
\hline B-Kes & $1.26 \pm 0.10^{a b}$ & ${ }^{b} 0.24 \pm 0.01^{a b}$ & $0.69 \pm 0.03^{a}$ & $1.43 \pm 0.10^{\mathrm{bcd}}$ & $0.17 \pm 0.02^{\mathrm{bc}}$ & $7.00 \pm 0.45^{b c}$ & $28.85 \pm 2.28^{c}$ & $65.85 \pm 9.17^{\mathrm{ab}}$ & $17.49 \pm 1.46^{c d}$ \\
\hline B-Bey & $1.27 \pm 0.09 \mathrm{ab}$ & ${ }^{b} 0.20 \pm 0.02^{c d}$ & $0.74 \pm 0.04^{a}$ & $1.33 \pm 0.05^{d}$ & $0.21 \pm 0.02^{a}$ & $7.66 \pm 0.63^{b}$ & $21.27 \pm 1.05^{d}$ & $51.05 \pm 5.09^{c}$ & $14.98 \pm 1.05^{\text {ef }}$ \\
\hline A-Sor & $1.32 \pm 0.09^{a}$ & $0.22 \pm 0.01 \mathrm{bc}$ & ${ }^{c} 0.73 \pm 0.01^{a}$ & $1.57 \pm 0.23 \mathrm{abc}$ & $0.17 \pm 0.01^{b c}$ & $7.37 \pm 0.86^{b c}$ & $36.98 \pm 6.72^{b}$ & $66.21 \pm 5.68^{a b}$ & $18.73 \pm 0.62^{b c}$ \\
\hline E-Yuk & $1.19 \pm 0.05^{b}$ & $0.21 \pm 0.02^{c}$ & $0.66 \pm 0.08 \mathrm{ab}$ & $1.44 \pm 0.11^{\mathrm{bcd}}$ & $0.12 \pm 0.01^{d}$ & $6.15 \pm 1.06^{c}$ & $35.45 \pm 2.02^{b}$ & $51.19 \pm 2.16^{c}$ & $16.31 \pm 2.12$ de \\
\hline E-Bal & $1.34 \pm 0.08^{a}$ & $0.20 \pm 0.02^{\mathrm{cd}}$ & $0.67 \pm 0.08$ & $1.67 \pm 0.19^{a}$ & $0.17 \pm 0.01^{b c}$ & $6.25 \pm 1.15^{c}$ & $30.90 \pm 0.28^{c}$ & $76.75 \pm 10.65^{a}$ & $19.71 \pm 0.66^{a b}$ \\
\hline Mean & $1.29 \pm 0.09$ & $0.22 \pm 0.03$ & $0.69 \pm 0.06$ & $1.49 \pm 0.19$ & $0.18 \pm 0.03$ & $7.03 \pm 1.26$ & $33.19 \pm 6.67$ & $62.01 \pm 11.66$ & $17.86 \pm 2.88$ \\
\hline Range & $1.12-1.57$ & $0.15-0.28$ & $0.51-0.77$ & $1.24-1.97$ & $0.11-0.25$ & $4.43-11.10$ & $20.11-45.14$ & $42.52-94.67$ & $12.12-23.32$ \\
\hline$F$ & 1.924 & 11.505 & 3.007 & 3.198 & 8.299 & 6.848 & 19.563 & 7.532 & 28.020 \\
\hline$p$ & 0.098 & $<0.001$ & 0.015 & 0.011 & $<0.001$ & $<0.001$ & $<0.001$ & $<0.001$ & $<0.001$ \\
\hline
\end{tabular}




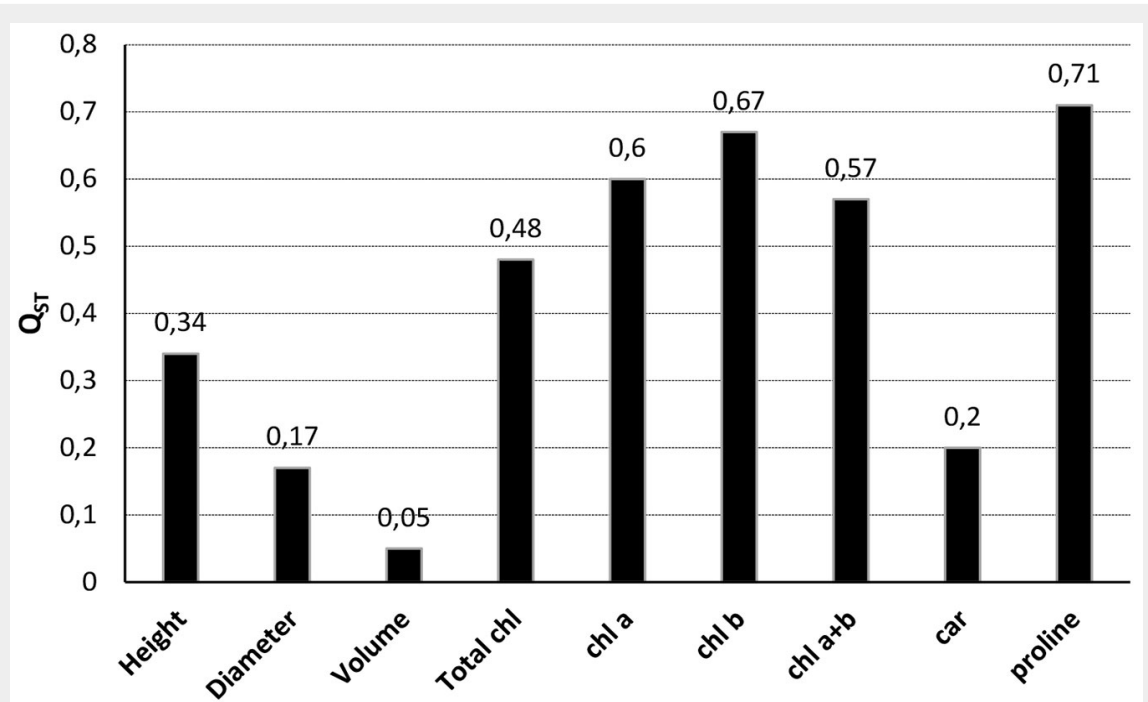

Fig. 4 - Phenotypic trait differentiation $\left(Q_{\mathrm{sT}}\right.$ ) values among J. excelsa populations (except Eğirdir-Barla and Eğirdir-Yukarigökdere populations). (Total chl): total chlorophyll; (chl $a, b$ and $a+b$ ): chlorophyll $a, b$ and $a+b$; (car): carotenoid.

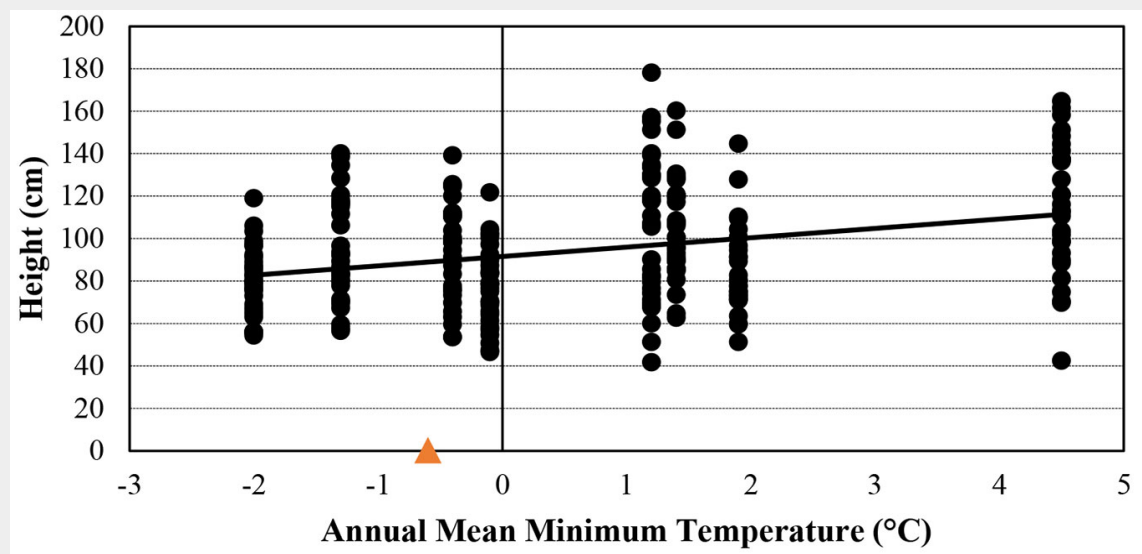

Fig. 5 - Correlation between annual mean minimum temperature $\left({ }^{\circ} \mathrm{C}\right)$ at populations' origin and height of $\mathrm{J}$. excelsa 10 -year-old saplings. The orange triangle indicates the mean annual minimum temperature at the common garden $\left(-0.6^{\circ} \mathrm{C}\right)$.

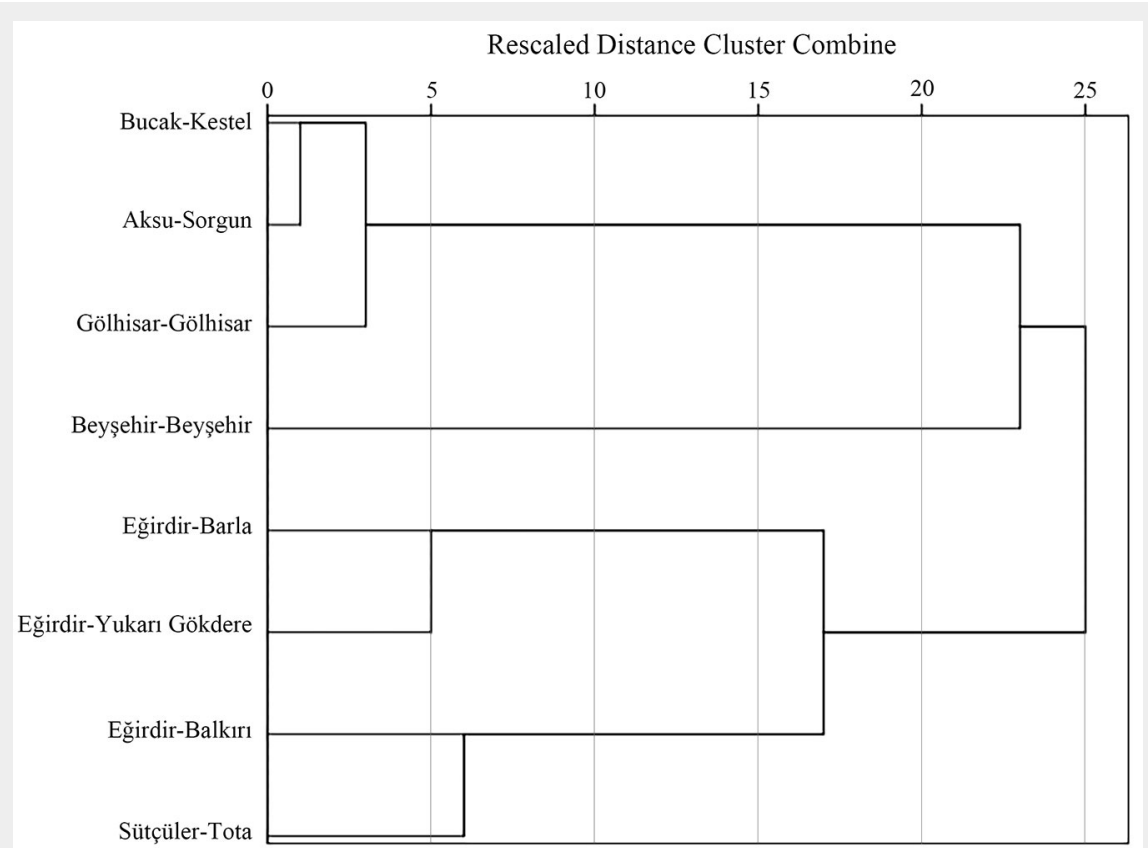

Fig. 6 - Dendrogram of hierarchical cluster analysis based on averages of all traits. ameter growth (Fig. 5).

Total mean precipitation, annual mean temperature, precipitation effectiveness index and altitude had no correlation with growth, photosynthetic pigments and proline $(p>0.05-$ Tab. S2 in Supplementary material). No environmental variables were associated with leaf nutrient contents (Tab. S3).

A hierarchical cluster analysis based on averages of all traits was performed to quantify similarities among the populations. This analysis distinguished two main groups at the 25 rescaled distance units, comprising E-Yuk and E-Bar populations in the first group, and A-Sor, G-Göl, B-Kes, EBal and S-Tot populations in the second group. The southwestern populations GGöl and B-Kes grouped together in the hierarchical cluster analysis confirming a weak phylogeographic pattern (Fig. 6). This hierarchical clustering corresponded with the results of Duncan tests relating to photosynthetic pigments, proline and nutrient contents (Tab. 2, Tab. 3).

\section{Discussion}

\section{Survival and growth}

Survival rate plays an important role in assessing the genetic variability among populations of different geographic origins when facing new environmental conditions (Apostol et al. 2020). In the present study, survival rate of all populations ten years after planting was determined as $100 \%$. This value was higher than the findings of Ortel et al. (2020) stating that one-year-old containerized saplings of $J$. excelsa obtained from only one population (Eğirdir-Çamdağ) had a survival rate of more than $82 \%$ in the third year of a field experiment in Yalvaç, Isparta that was $150 \mathrm{~km}$ away from test site in the current study. These results confirmed that J. excelsa would be successful in the afforestation of dry and cold environments.

In the present study, significant variation in height and diameter was found among eight populations of J. excelsa growing in the Davraz Common Garden test site. EBar, S-Tot and E-Yuk populations were above the general averages of height, diameter and volume at age 10 compared to all the other populations. The test site had no similarity in altitude and environmental variables with the E-Bar population but showed a similarity in altitude and climate type with S-Tot population. The mean values of height and diameter of J. excelsa saplings at age 10 were $94.47 \mathrm{~cm}$ and 41.6 $\mathrm{mm}$, respectively. Previous studies reported that the mean height of the species' saplings at age 8 in Burdur afforestation areas ranged from 80 to $151 \mathrm{~cm}$ (Cetin 2014), and the mean diameter at age 3 in IspartaYalvaç afforestation experiment was 8.86 $\mathrm{mm}$ (Ortel et al. 2020). The reason for the lower height and diameter in the present study may be related to environmental differences between sites (north exposure, 
high altitude, shallow soil, steep slope at the test site).

E-Bal population (1493 m a.s.l.) can be considered as local population, as its origin was situated closer (about $10 \mathrm{~km}$ ) to the test site $(1500 \mathrm{~m})$ as compared to the other populations, but surprisingly it showed lower growth compared to the mean of populations in terms of height and diameter at age 10. However, E-Bar population, located about $20 \mathrm{~km}$ from the test site, from lower altitude (1027 $\mathrm{m}$ a.s.l.) with higher annual mean temperature $\left(13.8^{\circ} \mathrm{C}\right)$, had the best performance at age 10 in terms of height, diameter and volume. On the contrary, the height and diameter of 10-year-old saplings from southwestern populations B-Kes and G-Göl (1197 and 1413 $\mathrm{m}$ a.s.l., respectively) were generally below the mean of populations at the test site. Boshier \& Stewart (2005) emphasized that as the use of highly fertile nursery soil largely affects differences in growth among provenances as compared to traditional provenance trials, it is hard to conclude on the extent of local adaptation until several years after planting out in the field. In this sense, the results of the current study, 10 years after the establishment of the test site, may potentially already show some patterns of local adaptation.

Due to the complex topography, no pattern of isolation by distance was detected. For example, populations B-Bey and A-Sor, phenotypically similar to each other as reflected in the dendrogram, were geographically close to the other northern populations (S-Tot, E-Bal, E-Bar and E-Yuk), but differentiated at phenotypic traits. Indeed, these two populations are separated by a mountain range (Dedegöl mountain) from the other northern populations and also have lower annual mean minimum temperature. The dendrogram in the present study is similar to that of the earlier study based on allele frequency differences at nuclear microsatellites (Yücedag \& Gailing 2013a). Similarly, Li et al. (2019) stressed that the barrier effects of mountains contributed to shape population differentiation of Chinese fir (Cunninghamia konishii) in Taiwan.

While there was no correlation of altitude of populations with diameter and height in the current study, both growth traits of 2 and 7-year-old saplings of Picea abies (L.) Karst. in a common garden at 150 m elevation in southern Poland decreased sharply for provenances from higher altitudes (Oleksyn et al. 1998). Similarly, Wilczynski \& Kulej (2019) stated that the mean height of 4-year-old saplings of Abies grandis (D. Don) Lindl. from North America in a provenance trial in Krynica (Polish Carpathian Mts., $700 \mathrm{~m}$ a.s.l.) decreased for provenances from higher altitudes. Adaptation to a combination of environmental factors including temperature (see below) is likely related to the observed differences in growth.

The present study revealed that J. excelsa saplings originating from regions with sandy clay and higher annual mean minimum temperature grew faster than those from regions with sandy loam and lower annual mean temperature than at the test site. As the temperature in the region of populations' origin was higher and thus the vegetation period was longer, saplings from these regions were likely adapted to higher temperatures and a longer growing period might explain their faster growth. Similarly, earlier studies reported that 13 year-old saplings of Fraxinus americana, Betula alleghaniensis, Prunus serotina, Abies balsamea, Larix laricina, Picea glauca, Pinus banksiana and P. strobus (Carter 1996) and 3-year-old saplings of Pseudotsuga menziesii (Leites et al. 2012) from regions with higher annual mean minimum temperature grew better than those from lower annual mean minimum temperature across test sites. Additionally, Chakraborty et al. (2015) reported that in 24-year-old trees of $P$. menziesii there was a weak positive correlation between annual mean minimum temperature in the regions of origin of populations and growth.

However, populations from regions with similar environmental conditions (e.g., annual mean minimum temperature and soil texture) as at the test site showed comparatively low height and diameter growth. Likewise, no pattern of isolation by adaptation was detectable by plotting growth differences against environmental differences between the populations' origins. Thus, it can be concluded from the present study that environmental similarity may not be a good indicator of growth-related traits and stress symptoms (proline and chlorophyll content).

\section{Phytochemical analyses}

In J. excelsa, photosynthetic pigments and proline of leaf varied significantly among populations for 10 year-old seedlings. The mean values of $\mathrm{chl} a\left(0.297 \mathrm{mg} \mathrm{g}^{-1}\right.$ FW) and $b\left(0.138 \mathrm{mg} \mathrm{g}^{-1} \mathrm{FW}\right)$ in the present study were higher than those of chl $a$ ( $\left.0.231 \mathrm{mg} \mathrm{g}^{-1} \mathrm{FW}\right)$ and $b\left(0.79 \mathrm{mg} \mathrm{g}^{-1} \mathrm{FW}\right)$ found by Keles \& Everest (2008) for J. excelsa naturally growing at $1500 \mathrm{~m}$ a.s.l. between Mersin and Anamur in the Middle Taurus Mountains, southern Turkey. Considering the results of photosynthetic pigments and proline as a whole, it can be concluded that populations were not exposed to severe stress factors at the test site.

In the current study, all nutrient contents of leaves varied among the populations of J. excelsa. Gülser et al. (2013) also showed that there were significant differences in $\mathrm{N}$, $\mathrm{P}, \mathrm{Ca}, \mathrm{Fe}, \mathrm{Mn}, \mathrm{Zn}$, and $\mathrm{Cu}$ contents of their leaves (but not in $\mathrm{K}$ and $\mathrm{Mg}$ ) among nine natural populations of $J$. excelsa in Gevas county in eastern Turkey. Turner et al. (1977) reported that Mn was significantly different among eight provenances of Pseudotsuga menziesii (Mirb.) Franco in a test site, but no difference for the other nutrients ( $\mathrm{P}, \mathrm{Al}, \mathrm{Ca}, \mathrm{Mg}, \mathrm{K}$ and $\mathrm{Na}$ ). The nutrient concentration in the leaves of a species mostly relies on the inherent properties of the species and provenances rather than the quantity of nutrients in the soil in which they grow (Jayasankar et al. 2003). The concentrations of $\mathrm{N}, \mathrm{P}, \mathrm{Ca}, \mathrm{Mn}$ and $\mathrm{Zn}$ in $J$. excelsa leaves obtained from the present study were in accordance with those reported by Gülser et al. (2013) in J. excelsa, but the concentrations of $\mathrm{K}, \mathrm{Mg}, \mathrm{Cu}$ and $\mathrm{Fe}$ were lower.

In the present study, $\mathrm{Zn}$ and $\mathrm{Fe}$ in leaves were positively correlated with height and diameter of saplings, respectively. Accordingly, E-Bar and S-Tot populations with the highest diameters also had the highest $\mathrm{Zn}$ concentration in their leaves because these nutrients are effective in the photosynthesis process (Zvezdanovic \& Markovic 2009). Accordingly, height growth was strongly and positively correlated with $\mathrm{Zn}$ in the needles of Pinus sylvestris L. (Semerci et al. 2017). Although Rout \& Sahoo (2015) indicated that $\mathrm{Fe}$ and chlorophyll concentrations are often well correlated in green plants, such a correlation was not found in the present study. $\mathrm{N}$ and $\mathrm{Mg}$ are associated with chlorophyll biosynthesis, and a deficiency of these elements is responsible for a significant decrease in chlorophyll content in the leaves of Acacia nilotica ssp. indica (Krishan \& Toky 1995). Similarly, the present study showed a positive correlation of chlorophyll content with $\mathrm{N}$ and $\mathrm{Mg}$.

Total chl, chl $a$ and chl $a+b$ as an indicator of plant health was positively associated with annual mean maximum temperature at the populations' origin. This result may result from the adaptations to drought stress of populations from warmer regions. However, Klein et al. (2012) in Pinus halepensis stated that leaf chlorophyll concentration at the test site had no correlation with climatic conditions at the regions of provenances. These contrasting results may be explained by cardinal temperatures for each plant that control its growth and development (Fowells \& Means 1990). Proline content in the leaves of J. excelsa saplings from regions with high topographic wetness index was lower than for those with low topographic wetness index at the test site in the current study. Increased concentration of osmolytes such as proline prevents negative effects of dehydration as an adaptation to drought stress. Accordingly, plants for drier regions (low topographic wetness index) have a higher proline content as adaptation to water deprived environments (Ashraf et al. 2018). Furthermore, both photosynthetic pigments and nutrient contents had no correlation with altitude of populations in this study. In contrast, Keles \& Everest (2008) revealed that the contents of $\mathrm{chl} a$ and $b$ decreased in leaves of natural J. excelsa populations from high altitude. Decrease in the contents of chlorophyll may be associated with reductions in photosynthesis at 
high altitudes as compared with lower altitudes.

Phenotypic differentiation vs. differentiation at neutral markers

Phenotypic differentiation $\left(Q_{\text {ST }}\right)$ among $J$. excelsa populations for growth, photosynthetic pigments and proline ranged from $5 \%$ (volume) to $71 \%$ (proline). Proline, chl $a$, chl $b$ and chl $a+b$ showed a very high $Q_{\text {ST }}$ value, potentially indicative of local adaptation. However, $Q_{\text {ST }}$ is possibly overestimated for photosynthetic pigments and proline since the number of samples per population is low due to the comparatively high costs for the phytochemical analyses. Also, the $Q_{\text {st }}$ values estimated in the present study were considerably higher for most traits than the mean genetic differentiation $\left(F_{\mathrm{ST}}=0.03\right)$ among J. excelsa populations observed at four randomly selected nuclear microsatellite loci (Yücedag \& Gailing 2013a) suggesting local adaptation across a small geographic scale. However, $Q_{\text {sт }}$ values for height and diameter growth were comparatively low ( $8 \%$ and $11 \%$, respectively). High variation within populations (Fig. 2) indicates a phenotypic plastic response and potentially high genetic variation for growth related traits within populations. Common garden experiments at different sites are needed to evaluate phenotypic plasticity in response to different environments.

\section{Conclusions}

The present study is the first to provide variability in growth, photosynthetic pigments, proline and nutrient contents of different $J$. excelsa populations at a common garden test site. Sapling traits of eight J. excelsa populations from the Lakes District in Turkey at the test site showed that the origin of populations significantly influenced growth, photosynthetic pigments, proline and nutrient contents. E-Bar and STot populations showed the highest performance for the majority of traits at age 10 compared to all other populations. Thus, they are likely the most suitable provenances to these harsh environmental conditions (low annual mean temperature, shallow soil depth, water deprivation, north exposure). Nutrient contents in leaves were generally in the sufficiency range reported for plant growth. $Q_{\text {ST }}$ values in the present study were considerably higher than the mean genetic differentiation among $J$. excelsa populations observed at four nuclear microsatellite loci, suggesting different local adaptations of populations at a small geographic scale. However, populations from regions with similar environmental conditions as at the test site did not show a faster growth. Thus, it can be concluded from the present study that environmental similarity may not be a good indicator of growth-related traits.

The results of the present study can be useful in the early selection of provenances for J. excelsa for plantation efforts. Further studies should be done in order to assess traits related to drought tolerance such as water use efficiency, photosynthesis rate and stomatal conductance of saplings in the same test site.

\section{List of abbreviations}

The following abbreviations have been used throughout the paper:

- $Q_{\text {sт: }}$ Phenotypic trait differentiation

- $F_{S T}$ : Genetic differentiation

- Total chl: total chlorophyll

- chl a: chlorophyll a

- chl b: chlorophyll $b$

- chl $a+b$ : Chlorophyll $a+b$

- car: carotenoid

- TWI: topographic wetness index

- N: Nitrogen

- P: Phosphorous

- K: Potassium

- Ca: Calcium

- Mg: Magnesium

- Cu: Copper

- Mn: Manganese

Fe: Iron

- Zn: Zinc

\section{Acknowledgments}

We would like to express our thanks to Forest Engineer Suat Altinsoy for the assistance in the establishment of common garden test site, Mr. Ahmet Aydemir and Forest Engineer Sinan Yücedag for the assistance in the measurement of growth traits and in the collection of leaf samples.

\section{References}

Anonymous (2013). Illere ait mevsim ortalamalari (1970-2011) [Seasonal averages of provinces (1970-2011). Web Site. [online] URL: http:// www.mgm.gov.tr/veridegerlendirme/il-ve-ilcele r-istatistik.aspx?m=ISPARTA

Apostol EN, Stuparu E, Scarlatescu V, Budeanu M (2020). Testing Hungarian oak (Quercus frainetto Ten.) provenances in Romania. iForest - Biogeosciences and Forestry 13: 9-15. - doi: 10.3832/ifor3108-012

Ashraf MA, Iqbal M, Rasheed R, Hussain I, Perveen S, Mahmood S (2018). Dynamic proline metabolism: importance and regulation in water-limited environments. In: "Plant Metabolites and Regulation Under Environmental Stress" (Ahmad P, Ahanger MA, Singh VP, Tripathi DK, Alam P, Alyemeni MN eds). Academic Press, San Diego, CA, USA, pp. 323-336. - doi: 10.1016/B978-0-12-812689-9.00016-9

Barbati A, Scarascia Mugnozza G, Ayan S, Blasi E, Calama R, Canaveira P, Cicatiello C, Collalti A, Corona P, Del Rio M, Ducci F, Perugini L (2018). Adaptation and mitigation. In: "State of Mediterranean Forests 2018" (Bourlion N, Garavaglia V, Picard N eds). FAO, Rome, Italy and Plan Bleu, Marseille, France, pp. 128-146. [online] URL: http://books.google.com/books?id=Tmy1D WAAQBAJ

Bates L, Waldren RP, Teare ID (1973). Rapid determination of free proline for water-stress studies. Plant and Soil 39: 205-207. - doi: 10.100 7/BFoo018060

Boshier D, Stewart J (2005). How local is local?
Identifying the scale of adaptive variation in ash (Fraxinus excelsior L.): results from the nursery. Forestry 78: 135-143. - doi: 10.1093/fore stry/cpio13

Brancalion PHS, Rodrigues RR, Oliveira GCX (2015). When and how could common gardens be useful in the ecological restoration of longlived tropical plants as an aid to the selection of seed sources? Plant Ecology and Diversity 8: 8190. - doi: 10.1080/17550874.2013.879941

Carter KK (1996). Provenance tests as indicators of growth response to climate change in 10 north temperate tree species. Canadian Journal of Forest Research 26: 1089-1095. - doi: 10.1139/ x26-120

Chakraborty D, Wang T, Andre K, Konnert M, Lexer MJ, Matulla C, Schueler S (2015). Selecting populations for non-analogous climate conditions using universal response functions: The case of Douglas-fir in Central Europe. PLoS One 10 (8): e0136357. - doi: 10.1371/journal.pone. 0136357

Cetin M (2014). Burdur çevresi agaçlandirma ve erozyon kontrolü çalismalarinin degerlendirilmesi [Evaluation of afforestation and erosion control works around Burdur]. Publications of the General Directorate of Combating Desertification and Erosion, Ankara, Turkey, pp. 182. [In Turkish]

Douaihy B, Vendramin GG, Boratynski A, Machon $\mathrm{N}$, Dagher-Kharrat MB (2011). High genetic diversity with moderate differentiation in Juniperus excelsa from Lebanon and the eastern Mediterranean region. AoB Plants 2011: plro03. doi: 10.1093/aobpla/plroo3

Douaihy B, Sobierajska K, Jasinska AK, Boratynska K, Ok T, Romo A, Machon N, Didukh Y, Dagher-Kharrat MB, Boratynski A (2012). Morphological versus molecular markers to describe variability in Juniperus excelsa subsp. excelsa (Cupressaceae). AoB Plants 2012: pls013. doi: 10.1093/aobpla/pls013

Eler U (1988). Türkiye'de boylu ardiç (Juniperus excelsa Bieb.) ormanlarinda hasilat arastirmalari [Yield studies for Crimean juniper (Juniperus excelsa Bieb.) forests in Turkey]. Publications of Forestry Research Institute, Ankara, Turkey, pp. 70. [In Turkish]

Erinç S (1965). Yagis müessiriyeti üzerine bir deneme ve yeni bir indis [An essay on the effectiveness of precipitation and a new index]. Publications of Geography Institute of Istanbul University, Istanbul, Turkey, pp. 51. [In Turkish]

FAO (2020). Soil testing methods. Food and Agriculture Organization, United Nations, Rome, Italy, web site. [online] URL: http://www.fao. org/3/ca2796en/CA2796EN.pdf

Fowells HA, Means JE (1990). The tree and its environment. In: "Silvics of North America" (Burns RM, Honkala BH eds). USDA Forest Service, Washington, DC, USA, pp. 2-11. [online] URL: http://books.google.com/books?id=5BOM hhO1d4C

Gülser F, Türkoglu N, Cig A (2013). The determination of nutrient contents of native juniper (Juniperus excelsa Bieb) leaves related with soil properties in Van region. In: Proceedings of the "International Caucasian Forestry Symposium". Artvin (Turkey) 24-26 Oct 2013, pp. 570-573. [online] URL: http://hdl.handle.net/20.500.12604/15 20 
Gulsoy AD, Gulsoy AM, Duman H, Kaya Z (2012). Molecular phylogeny of Juniperus species in Turkey based on noncoding trn region of cpDNA. In: Proceedings of the "International Symposium on the Biology of Rare and Endemic Plant Species (BIORARE 2012)". Mugla (Turkey), 23-27 April 2012, pp. 39.

Hill WG, Goddard ME, Visscher PM (2008). Data and theory point to mainly additive genetic variance for complex traits. PLoS Genetics 4: 1-10. doi: 10.1371/journal.pgen.0040001

Hojjati F, Zarre S, Assadi M (2009). Isoenzyme diversity and cryptic speciation in Juniperus excelsa (Cupressaceae) complex in Iran. Biochemical Systematics and Ecology 37: 193-200. - doi: 10.1016/j.bse.2009.03.002

Isaac-Renton M, Montwé D, Hamann A, Spiecker $H$, Cherubini $P$, Treydte K (2018). Northern forest tree populations are physiologically maladapted to drought. Nature Communications 9 (1): 987. - doi: 10.1038/s41467-018-07701-0

Jayasankar S, Sudhakara K, Babu LC (2003). Provenance variation in growth, physiology, anatomical characteristics and foliar nutrient status of teak (Tectona grandis) seedlings. Journal of Tropical Forest Science 15 (1): 37-50. [online] URL: http://www.jstor.org/stable/23616323 Keles Y, Everest A (2008). Relation to altitude adaptation and antioxidant defense system in five shrubs and trees species from middle Taurus Mountains. International Journal of Natural and Engineering Sciences 2: 45-49.

Kilinç M, Kutbay HG, Yalçin E, Bilgin A (2006). Bitki ekolojisi ve bitki sosyolojisi uygulamalari [Plant ecology and plant sociology applications]. Palme Publishing, Ankara, Turkey, pp. 362. [In Turkish]

Kjeldahl J (1883). New method for the determination of nitrogen. Chemistry News 48 (1240): 101-102.

Klein T, Di Matteo G, Rotenberg E, Cohen S, Yakir $D$ (2012). Differential ecophysiological response of a major Mediterranean pine species across a climatic gradient. Tree Physiology 33: 26-36. doi: 10.1093/treephys/tps116

Krishan B, Toky OP (1995). Variation in foliar biochemical and nutrient contents among provenances of Acacia nilotica ssp. indica. Journal of Tropical Forest Science 8 (1): 78-86. [online] URL: http://www.jstor.org/stable/43582158

Leites LP, Robinson AP, Rehfeldt GE, Marshall JD, Crookston NL (2012). Height-growth response to climatic changes differs among populations of Douglas-fir: a novel analysis of historic data. Ecological Applications 22 (1): 154165. - doi: 10.1890/11-0150.1

Li Y, Wu X, Chen T, Wang W, Liu G, Zhang W, Li S, Wang M, Zhao C, Zhou H, Zhang G (2018). Plant phenotypic traits eventually shape its microbiota: a common garden test. Frontiers in $\mathrm{Mi}$ crobiology 9: 2479. - doi: 10.3389/fmicb.2018. 02479

Li Y-S, Shih K-M, Chang C-T, Chung J-D, Hwang S$Y$ (2019). Testing the effect of mountain ranges as a physical barrier to current gene flow and environmentally dependent adaptive divergence in Cunninghamia konishii (Cupressaceae) Frontiers in Genetics 10: 742. - doi: 10.3389/f gene.2019.00742
Lichtenthaler HK (1987). Chlorophylls and carotenoids: pigments of photosynthetic biomembranes. Methods in Enzymology 148: 350-382. doi: 10.1016/0076-6879(87)48036-1

Manzanedo RD, Schanz FR, Fischer M, Allan E (2018). Fagus sylvatica seedlings show provenance differentiation rather than adaptation to soil in a transplant experiment. BMC Ecology 18 (1): 669. - doi: 10.1186/s12898-018-0197-5

Miller RO (2004). High-temperature oxidation: Dry ashing. In: "Handbook of Reference Methods for Plant Analysis" (Kalra YP ed). CRC Press, Florida, USA, pp. 53-56. - doi: 10.1201/978 1420049398

Oleksyn J, Modrzynksi J, Tjoelker MG, Zytkowiak R, Reich PB, Karolewski P (1998). Growth and physiology of Picea abies populations from elevational transects: common garden evidence for altitudinal ecotypes and cold adaptation. Functional Ecology 12: 573-590. - doi: 10.1046/j. 1365-2435.1998.00236.x

Ortel E, Kavgaci A, Calikoglu M, Türkkan M, Gültekin HC, Cobanoglu A (2020). Boylu ardicin (Juniperus excelsa) yapay gençlestirilmesi [Artificial regeneration of Crimean juniper (Juniperus excelsa)]. Turkish Journal of Forestry Research 7 (1): 22-30. [in Turkish]

Pakharkova N, Borisova I, Sharafutdinov R, Gavrikov V (2020). Photosynthetic pigments in Siberian pine and fir under climate warming and shift of the timberline. Forests 11: 1-15. - doi: 10.3390/f11010063

Qin C-Z, Zhu A-X, Pei T, Li B-L, Scholten T, Behrens T, Zhou C-H (2011). An approach to computing topographic wetness index based on maximum downslope gradient. Precision Agriculture 12: 32-43. - doi: 10.1007/s11119-009-9152-y Rout GR, Sahoo S (2015). Role of iron in plant growth and metabolism. Reviews in Agricultural Science 3: 1-24. - doi: 10.7831/ras.3.1

Sáenz-Romero C, Kremer A, Nagy L, Ujvari-Jarmay E, Ducousso A, Koczan-Horvath A, Hansen JK, Matyas C (2019). Common garden comparisons confirm inherited differences in sensitivity to climate change between forest tree species. Peer J - Life and Environment 7: 6213. - doi: 10.7717/peerj.6213

Schreiber P (1904). Uber die Beziehungen zwischen dem Niederschlag und der Wasserführung der Flüsse in Mitteleuropa [The relationship between precipitation and the water flow of rivers in Central Europe]. Meteorologische Zeitschrift 21: 441-452. [in German]

Semerci A, Semerci H, Caliskan B, Ciçek N, Ekmekçi Y, Mencuccini M (2017). Morphological and physiological responses to drought stress of European provenances of Scots pine. European Journal of Forest Research 136: 91-104. doi: 10.1007/s10342-016-1011-6

Sewenet HK (2019). A review on comparison of complete and incomplete block designs. Journal of Biology, Agriculture and Healthcare 9 (9): 15-24. [online] URL: http://core.ac.uk/down load/pdf/234662824.pdf

Shah SH, Houborg R, McCabe MF (2017). Response of chlorophyll, carotenoid and SPAD502 measurement to salinity and nutrient stress in wheat (Triticum aestivum L.). Agronomy 7: 61. - doi: 10.3390/agronomy7030061
Shtangeeva I, Tesfalidet S, Lövgren L (2017). Comparison of nutrient concentrations in leaves of five plants, Journal of Plant Nutrition 40: 239-247. - doi: 10.1080/01904167.2016.1237 647

Sillanpaeae M (1991). Micronutrient assessment at the country level: an international study. FAO, Rome, Italy, pp. 214.

Spitze K (1993). Population structure in Daphnia obtuse - quantitative genetic and allozymic variation. Genetics 135: 367-374. - doi: 10.1093/ genetics/135.2.367

Turner J, Dice SF, Cole DW, Gessel SP (1977). Variation of nutrients in forest tree foliage. Publications of University of Washington, Seattle, Washington, USA, pp. 31. [online] URL: http://ir. library.oregonstate.edu/concern/defaults/sx61d $\mathrm{n} 48 \mathrm{k}$

Vizcaíno-Palomar N, Garzón MB, Alia R, Giovannelli $G$, Huber G, Mutke S, Pastuszke P, Raffin A, Sbay H, Seho M, Vauthier D, Fady B (2019). Geographic variation of tree height of three pine species (Pinus nigra Arn., P. pinaster Aiton, and $P$. pinea L.) gathered from common gardens in Europe and North-Africa. Annals of Forest Science 76: 77. - doi: 10.1007/s13595-019-0867-2

Wilczynski S, Kulej M (2019). The growth of seven Abies grandis provenances in the climatic conditions of the Polish Carpathian Mountains. Dendrobiology 81: 1-13. - doi: 10.12657/denbio. 081.001

Yücedag C, Gailing O (2013a). Genetic variation and differentiation in Juniperus excelsa M. Bieb. populations in Turkey. Trees - Structure and Function 27: 547-554. - doi: 10.1007/s00468-0120807-3

Yücedag C, Gailing O (2013b). Differences among Juniperus excelsa populations as revealed at morphological traits. Dendrobiology 70: 65-72. doi: 10.12657/denbio.070.007

Zvezdanovic J, Markovic D (2009). Copper, iron, and zinc interactions with chlorophyll in extracts of photosynthetic pigments studied by VIS spectroscopy. Russian Journal of Physical Chemistry A 83: 1542-1546. - doi: 10.1134/S0036 024409090222

\section{Supplementary Material}

Fig. S1 - Correlation between annual mean maximum temperature $\left({ }^{\circ} \mathrm{C}\right)$ at populations' origin and total chlorophyll (chl), chl $a$ and chl $a+b$.

Tab. S1 - Correlation coefficients between the pairs of all the traits.

Tab. S2 - Correlation coefficients for the associations of the environmental variables at the region of populations with growth, photosynthetic pigments and proline.

Tab. S3 - Correlation coefficients for the associations of environmental variables with leaf nutrient contents.

Link: Yucedag_3769@supploo1.pdf 